\title{
Ex crimine liability of legal persons in EU legislation. An Overview of Substantive Criminal Law
}

\author{
Nicola Selvaggi ${ }^{\star}$
}

This article aims to understand if establishing responsibility of legal entities for offences within legislative instruments enacted in the exercise of competence provided for by the Lisbon Treaty will contribute to the evolution of European discipline of this type of liability. This, both from the point of view of its qualification (which could evolve into a proper criminal or at least quasicriminal responsibility) and of its contents, with special regard to the imputation criteria the discipline of which should evolve in order to be more respectful of the principles relating to the conditions of criminal liability (or liability similar thereof).

From the perspective of the nature of the responsibility, it seems that whenever ex crimine liability of corporations is specifically referred to within acts adopted under (in particular) Art. 83 of the Lisbon Treaty, Member States should choose among sanctions which may be applied to collective entities, those correspondent to the highest afflictive level.

On the side of the liability regime, 'specifics' of ex crimine liability (whether proper criminal liability or a type of liability similar thereof) call for an innovation of the imputation mechanism that can be shaped by EU acts, in order to go beyond the 'minimum standard' currently provided by EU legislative instruments and to give relevance (introducing a specific imputation criterion or at least providing for a defence) to a fault of the corporate body; and open the way for a legal entity which is properly and effectively organized to be insulated from responsibility.

\section{Preliminary remarks}

The increase of offensive (and often cross-borders) activities carried out by legal entities, particularly in the economic field, to the detriment of the EU's interests (mainly financial ones) and other common interests has led the Union's Institutions to set up a system of protection over the years in which direct liability ex crimine of corporations plays a significant role ${ }^{1}$.

\footnotetext{
* Assistant Professor of Criminal Law, University 'Mediterranea' of Reggio Calabria.

${ }^{1}$ It should be underlined that, as most recently emphasised by the 2009 Stockholm Programme, economic and financial crime prevention is at the top of the European criminal policy agenda. An analysis of existing international instruments, especially those of the European Union and Council of Europe, with a survey of preconditions for corporate liability and the respective sanctions, is in Engelhart, Unternehmensstrafbarkeit im europäischen und internationalen Recht, in Eucrim, 2012/3, 110 et seq.; Pieth, Ein europäisches Unternehmensstrafrecht?, in Kempf, Lüderssen, Volk (ed.), Unternehmensstrafrecht, Berlin, 2012, 395 ss.; Pieth, Ivory, Emergence and Convergence: Corporate Criminal Liability Principles in Overview, in Pieth, Ivory (ed.), Corporate Criminal Liability. Emergence, Convergence, and Risk, Springer, 2011, 9-12; Manacorda, La responsabilité des personnes morales et l'harmonisation pénale européenne: modèles normatifs et obstacles théoriques, in Giudicelli-Delage, Manacorda, La responsabilité pénale des personnes morales: perspectives européennes et internationales, Paris, 2013, 23 et seq.; Tricot, L'acquis «indirect» européen en matière de responsabilité pénale des personnes morales. L'apport des instruments de coopération judiciaire, ibidem, 47 et seq.; see also Tiedemann, Strafrechtliche Verbandsverantwortung in Europa: Referenzmodelle für die Gesetzgebung und aussichten für eine Harmonisierung, in Rivista trimestrale di diritto penale dell'economia, 2012/1-2, 9-13 ; Dannecker, Das Unternehmen als " Good Corporate Citizen » - ein Leitbild
} 
Direct liability of legal entities ${ }^{2}$ has become an important tool since it helps to prevent and sanction serious offences in important EU policy areas; and also to tackle those serious crimes which occur across borders, so as to avoid the possibility of choosing the Member State with the most lenient sanctioning system and accordingly realizing, in EU area, a sort of 'Delaware effect' 3 .

Such a trend progressed alongside the evolution of EU competencies on criminal law; thus, over time the number of legal instruments pushing Member States towards the adoption of proportionate, effective, and dissuasive sanctions against legal entities has, as well, steadily increased.

The typology of the said instruments takes into account evolutions of the institutions and the legal orders that have characterized, into its current shape, the European Union, thus making clear why ex crimine liability is referred to equally in Conventional acts (as regards the Second Protocol to P. I. F. Convention on protection of financial interests), in joint actions (among others, see Art. 3, joint action 21st December 1998 on organized crime), in framework decisions (see, for example, Framework Decision 2003/568/JHA of the Council of 22 July 2003 on combating corruption in the private sector; Framework 2008/841/JHA of the Council of 24 October 2008 on the fight against organized crime) and, lastly, in directives (Directive 2011/92/EU of European Parliament and Council of 13 December 2011 on combating the sexual abuse and sexual exploitation of children and child pornography; Directive 2011/36/EC of European Parliament and Council of 5 April 2011 on preventing and combating trafficking in human beings and protecting its victims; Directive 2009/52/EC of European Parliament and Council of 18 June 2009, providing for minimum standards on sanctions and measures against employers of illegally staying third-country nationals; Directive 2009/123/EU of 21 October 2009 on ship-source pollution and on the introduction of penalties for infringements).

At present, instruments which are due for adoption derive from 'criminal' competencies granted by the Lisbon Treaty ${ }^{4}$.

der europäischen Rechtsentwicklung ?, in Alwart (ed.), Verantwortung und Steuerung von Unternehmen in der Marktwirtschaft, München und Mering, 1998, 5 et seq.

${ }^{2}$ Variety of National laws on collective entities explains why European instruments essentially focus on the main structure of the collective phenomenon, i. e. the 'legal person', leaving aside other delicate issues like, for instance, that of 'group of companies' as a possible recipient of sanctions. Here, as well as in other cases, National legislators are kept free to widen or tighten the subjective scope of liability. Only exception is the State, other public entities whenever they carry out public duties - and public International organizations (excluding, for instance, so called 'non-governmental' or 'non-profit' ones): these, indeed, usually do not constitute 'legal person' as provided for in EU instruments on liability. It is in general specified that 'legal person' shall mean any entity having legal personality under the applicable law, except for States or public bodies in the exercise of State authority and for public international organizations. See Giudicelli-Delage, Le champ personnel et matériel, in Fiorella (ed.), Corporate Criminal Liability and Compliance programs, II, Towards a Common Model in the European Union, Napoli, 2012, 20 et seq.; Massi, 'Veste formale' e 'corpo organizzativo' nella definizione del soggetto responsabile per l'illecito da reato, Napoli, 2012, 151 et seq.

${ }^{3}$ On the risk of a 'forum shopping', see Adam-Vermeulen-De Bondt, Corporate Criminal Liability and the EC/EU: Bridging Sovereignty Paradigms for the Sake of an Area of Justice, Freedom and Security, in Adam-Colette-Basecqz-Nihoul, La responsabilité pénale des personnes morales en Europe, Bruxelles, 2008, 385-386.

${ }^{4}$ See for Lisbon Treaty provisions, the contributions in Grasso-Picotti-Sicurella, L'evoluzione del diritto penale nei settori d'interesse europeo alla luce del Trattato di Lisbona, Milano, 2011; Sicurella, Some Reflections on the Need for a General Theory of the Competence of the European Union in Criminal Law, in Klip (ed.), Substantive Criminal Law of the European 
Among them, the proposal of a directive on 'criminal sanctions for insider dealing and market manipulation' is based on Article 83.2 of the TFEU. As stated in the explanatory memorandum, since it often occurs across borders, market abuse harms the integrity of financial markets which are increasingly integrated in the Union. The divergences within domestic discipline leave a certain scope for perpetrators who can often take benefit from the most lenient sanction system, which 'undermines both the deterrent effect of each national sanction regime and the effectiveness of enforcement of the Union's legislative framework on market abuse. EUwide minimum rules on the forms of market abuse that are considered to be a criminal conduct contribute to addressing this problem. Against this background EU action appears appropriate in terms of the principle of subsidiarity'.

Also, the proposal for a directive 'on the fight against fraud to the Union's financial interests by means of criminal law' which provides for the legislative procedure to adopt the necessary measure with a view to affording effective and equivalent protection and also for a legal base to legislate on fraud and any other illegal activity affecting the Union's financial interests in the fields of the prevention and the fight against fraud ${ }^{5}$. As declared in the proposal's explanatory memorandum, 'the fight against illegal activities affecting the Union's financial interests is a very specific policy area, as the provision's positioning in a special chapter dedicated to 'combating fraud' in the title on 'financial provisions' in the Treaty indicates. This shows that in this specific field, the Union has a broad array of tools at its disposal. This peculiarity is further strengthened by Article 310 (6) TFEU which already in the very first article of the Title on financial provisions underscores the need to fight illegal activities affecting the Union's financial interests'.

The present study aims to understand if establishing responsibility of legal entities for offences within legislative instruments enacted in the exercise of competence provided for by the Lisbon Treaty will contribute to the evolution of the European discipline of this type of liability. This, both from the point of view of its qualification (that could evolve to a proper criminal or at least quasi-criminal responsibility) and of its contents, with special regard to the imputation criteria whose discipline should evolve in order to be more respectful of the principle of personality ${ }^{6}$.

Union, Antwerpen, 2011, 233 et seq.; Satzger, Internationales und Europäisches Strafrecht, Baden-Baden, 2011, 116 et seq.; Arroyo Zapatero, Muñoz de Morales, L'harmonisation autonome, in Le droit penal de l'Union européenne au lendemain du Traite de Lisbonne, Paris, 2011; Nieto Martín, The Treaty of Lisbon and the Stockholm programme: the consolidation of European Criminal Law, in Arroyo Zapatero- Nieto Martín (ed.), European Criminal Law: An Overview, Cuenca, 2010, 41 et seq.; Vervaele, Sviluppo storico del diritto penale speciale e del diritto penale economico e finanziario, in Rivista trimestrale di diritto penale dell'economia, 2011, 551-558; Foffani, Il 'Manifesto sulla politica criminale europea', in Criminalia, 2010, 657-671; Sotis, Le novità in tema di diritto penale europeo, in Bilancia-D'Amico, La nuova Europa dopo il Trattato di Lisbona, Milano, 2009, 137 et seq.

${ }^{5}$ See Venegoni, Prime brevi note sulla proposta di direttiva della Commissione Europea per la protezione degli interessi finanziari dell'Unione attraverso la legge penale COM(2012)363 (c.d. Direttiva PIF), in www.penalecontemporaneo.it

${ }^{6}$ On the issues concerning procedural guarantees which could be recognized to legal entities see the contributions in Kempf, Lüderssen, Volk (ed.), Unternehmensstrafrecht, above mentioned at ft. 1, 335 et seq.; Schlüter, Die Strafbarkeit von Unternehmen in einer prozessualen Betrachtung nach geltenden Strafprozessrecht, Frankfurt, 2000, 82 et seq.; Lampe, Verfahrensgrundlinien zur Verhängung von Maßnahmen gegen Wirtschaftsverbände, in Schünemann, Alternativentwurf Europäische Strafverfolgung, Köln, 2004, 101 et seq.; Arzt, Schutz juristischer Personen gegen Selbstbelastung, in JZ, 2003, 456457 (with special regard to the right of silence). 
In this perspective, despite this work being mainly devoted to acts drafted by the EU, one cannot fail to give evidence of the contribution coming from the Council of Europe which, even before the Convention on bribery signed by the States, set forth its position on direct liabilities of legal entities, especially through a series of recommendations [see, in particular, R. (77) 28, R. (81) 12, R. (82) 15 e R. (88) 18] where States are referred to the value and usefulness of making legal persons directly responsible for crimes committed in carrying out their activities $^{7}$.

\section{Towards (a proper) criminal liability of legal entities? The 'construc- tive ambiguity' under the Lisbon Treaty provisions}

An effective system of protection by sanctioning tools usually implies (at least as a tendency) some uniformity with regard to the nature of sanctions and the liability regime.

As far as legal persons are concerned, in general EU legislative acts only indicate that Member States shall take measures to introduce direct responsibility, regardless of the nature of such liability and thus of the corresponding sanctions. As outlined, what is crucial is not the legal denomination of sanctions, but rather their being effective, dissuasive and proportionate ${ }^{8}$.

From this point of view, EU law shapes an ex crimine liability so as to mean that an entity should not be safeguarded from consequences (whether penal, administrative or even civil) directly deriving from a criminal offence, whereas requisites for charging the corporate body with the fact occur. But no mention is given to the nature of the said responsibility.

\footnotetext{
${ }^{7}$ See again Engelhart, Unternehmensstrafbarkeit im europäischen und internationalen Recht, above mentioned at fn. 1, 118-119; De Vel, La responsabilité pénale des personnes morales dans les instruments juridiques du Conseil de l'Europe, in Adam-Colette-Basecqz-Nihoul, La responsabilité pénale des personnes morales en Europe, above mentioned (at fn. 1), 343-371; de Vero, La responsabilità penale delle persone giuridiche, in Trattato di Diritto Penale (directed by Grosso, Padovani, Pagliaro), Milano, 2008, 105-106; de Maglie, L'etica e il mercato. La responsabilità penale delle società, Milano, 2002, 231 et seq.; Palazzo, L'influenza dell'attività del Consiglio d'Europa sul diritto penale italiano, in AA. VV., L'influenza del diritto europeo sul diritto italiano, Milano, 1982, 633 et seq.

${ }^{8}$ See, Mongillo, The Nature of Corporate Liability for Criminal Offences, in Fiorella (ed.), Corporate Criminal Liability and Compliance Programs, II. Towards a Common Model in the European Union, Napoli, 2012, 98 et seq. In some cases (for the past, in particular refer to frame-work decisions; currently, see, e. g., the mentioned proposal for a directive on the safeguard of EU's financial interests) indications are more complex; as often not only fines are provided for, but disqualification or placement under judicial supervision as well. In general, it is not unusual that sanctions other than fines are listed following this directory, referred to as 'minimum' and 'sufficient': a) exclusion from entitlement to public benefits or aid; b) temporary or permanent disqualification from the practice of commercial activities; c) placing under judicial supervision; d) judicial winding-up; e) temporary or permanent closure of establishments which have been used for committing the offence. As stated, the provisions in the EU legislation regulating the liability of legal entities are the fruit of a complicated consensus between different legal traditions: 'Constructive ambiguity - a well-known legislative technique in international law - is the tool used in order to describe the imputation of liability and the sanction system. In the latter case, Directives and Framework decisions only provide the name of the sanction without describing the concrete aspects that those sanctions should contain, leaving room for a broad discretional action by Member States', Nieto-Martín, Sanction system and cooperation, in Giudicelli-Delage, Manacorda, La responsabilité pénale des personnes morales, at fn. 1,89.
} 
Recalling the Second Protocol, drawn up on the basis of Article K.3 of the Treaty on European Union, to the Convention on the protection of the European Communities' financial interests (hereinafter PIF Convention), which constitutes the underpinning of the majority of domestic discipline on this matter, said Protocol provides that each Member State shall take the necessary measures to ensure that a legal person held liable pursuant to Article 3 (1) is punishable by effective, proportionate and dissuasive sanctions, which shall include criminal or non-criminal fines.

As known, this wording recurs in the majority of legislative instruments containing provisions on liability of legal entities.

Also, the abovementioned proposal for a directive on the fight against fraud to the Union's financial interests by means of criminal law, provides for minimum sanction types for legal persons, stating that 'Member States shall take the necessary measures to ensure that a legal person held liable pursuant to Article 6 is subject to effective, proportionate and dissuasive sanctions, which shall include criminal or non-criminal fines (...)'.

This traditional approach (based on a sort of constructive ambiguity or 'functional equivalence'9 ) appears nevertheless 'challenged' by recent choices, which, while not expressly stating the 'criminal' nature of liability, seem to point in that direction, or at least to frame provisions in a context that, with respect to content and schemes, is to be considered properly criminal.

In particular, it is crucial from this point of view to consider which consequences might arise when discipline of liability is placed within legal instruments adopted pursuant to provisions in the Lisbon Treaty concerning criminal law competencies of the $\mathrm{EU}^{10}$.

In this case, is such liability conceived to be properly criminal? Or are Member States still free to choose and impose any kind of consequences (criminal or non criminal)?

With reference to Art. 83 of the TFEU, it may be interesting to note that this article could be considered as not constituting a valid legal basis for provisions requiring the responsibility of legal persons not (properly) considered as criminal, as this (i.e. to bind the States to introduce administrative or civil sanctions against collective entities) could be achieved by reference to other provisions of the Treaty (for example, Art. 114 TFEU). Therefore, it could not be excluded that a strict interpretation of the Lisbon Treaty on this point can lead to the idea that whenever ex crimine liability of corporations is specifically referred to within acts adopted under (in particular) Art. 83 of the Treaty of Lisbon, that is meant to refer (only) to criminal liability.

${ }^{9}$ Pieth, ,Fünktionale Äquivalenz': Praktische Rechtsvergleichung und internationale Harmonisierung von Wirtschaftsstrafrecht, in ZSR 119, 2000, p. 477 et seq.

${ }^{10}$ See Herlin-Karnell, The constitutional dimension of European criminal law, Oxford and Portland, Oregon, 2012, 182-183 noting that due to EU increasing involvement in criminal law, although it is true that the Court has been reluctant to explicit rules on criminal liability for legal persons 'it remains less certain whether in practice, Member States have much choice when asked to comply with effective sanctions. This poses potential difficulties for Member States that do not recognise criminal liability for legal persons'; also Peers, EU Justice and Home Affairs, Oxford, 2011, ch. 8 and 10 . 
This conclusion might nevertheless be drastic ${ }^{11}$.

Thus, a smoother interpretation of this emerging trend would consider that Member States, in these cases, should impose sanctions on legal entities that are as effective and dissuasive as those (properly and formally criminal) applied to individuals according to the domestic discipline.

To some extent, providing for sanctions to be imposed on legal entities, pursuant to an EU legal instrument adopted according to Art. 83 of the Lisbon Treaty, may imply for a Member State to choose, among sanctions which may be applied to collective entities, those correspondent to the highest afflictive level.

Confirmation of this perspective could be achieved recalling once again the abovementioned proposal for a directive on criminal sanctions for insider dealing and market manipulation.

As made clear in the explanatory memorandum, 'minimum rules on criminal offences and on criminal sanctions for market abuse, which would be transposed into national criminal law and applied by the criminal justice systems of the member States, can contribute to ensuring the effectiveness of this Union policy by demonstrating social disapproval of a qualitatively different nature compared to administrative sanctions or compensation mechanism under civil law'. This explanation is meant to be general and in this extent to refer also to liability of legal entities. On the other hand, the proposal (Article 8) only establishes that necessary measures to ensure that legal persons held liable pursuant to Article 7 are punishable by effective, proportionate and dissuasive sanctions are taken, without mentioning - as instead provided for by other instruments - that these sanctions may be of a criminal or non-criminal nature.

Building up a 'matière pénale', at least in the sense of ECHR case-law, would be, in other words, the standard to which Member States shall converge.

\section{No country for old...brocards? The situation in the EU area}

A significant role, in this perspective, may be played by the acknowledgment of the value undoubtedly to be attributed to the placement of entities' liability within the criminal system, which, as a means to obtain stronger prevention of crimes typical to organized activities (as arises, in particular, out of programmatic documents on 'criminal policy' in Europe) and, in the meantime, better safeguards for legal persons facing charges of having conspired - so to speak - to commit a crime $^{12}$.

\footnotetext{
${ }^{11}$ For the analysis of the 'acceptance of a national refusal of corporate criminal liability', as a principle related to indirect positive harmonization in EC law, with wide reference to case-law, Adam-Vermeulen-De Bondt, Corporate Criminal Liability and the EC/EU: Bridging Sovereignty Paradigms for the Sake of an Area of Justice, Freedom and Security, in Adam-Colette-Basecqz-Nihoul, La responsabilité pénale des personnes morales en Europe, above at fn. 3, 395-397, who also considers the possible impact of Lisbon Treaty provisions on this field, remarking that Art. 67 establishes that any measure adopted in the area of justice, freedom and security has to respect the 'different legal systems and traditions' 'Although it is doubtful whether this could serve as a reason in itself for annulment by the ECJ' (p. 430).

${ }^{12}$ It is, indeed, not without reason that the Council of Europe already stressed the need for criminal sanctions to entities in the late eighties, whenever requested in keeping with the nature and seriousness of the offence. In
} 
In fact, this belief over time led many countries of the EU to adopt proper criminal sanctions for entities, or at least other, similar forms of liability, such as those that are imposed by criminal judges and which are often quiet afflictive. As a result, an essentially common trend emerged, consisting in the vision of a criminal or 'quasi-criminal' sanctioning system which, shaped as such, could stabilize even further, aimed at the goal of better cooperation between States against the most aggressive forms of criminality.

Although this issue deserves a wider analysis, it is worth - for the purposes of this work - remembering that a proper corporate criminal liability is, by far, provided for by the majority of domestic laws ${ }^{13}$; besides, some Member States do provide for a sort of 'para-criminal' liability ${ }^{14}$ while only few exceptions still have an administrative sanctioning system ${ }^{15}$.

\section{A minimum standard: models of liability in current EU discipline}

Approximation to criminal law, at least as far as gravity of sanctions to be imposed to legal entities is concerned, should imply not only more harshness but also a more proportionate discipline of responsibility. In fact, realizing a truly effective and dissuasive sanctioning system for legal entities should also lead to rethink some of the contents of EU discipline on this matter, with particular reference to imputation criteria ${ }^{16}$.

In this perspective, it is worth briefly recalling how the liability regime has been shaped by European legislative instruments ${ }^{17}$.

particular R. (88) 18, in par. I, states that to render enterprises liable, consideration should be given in particular to a) applying criminal liability and sanctions to enterprises, where the nature of the offence, the degree of fault on the part of the enterprise, the consequences for society and the need to prevent further offences so require; applying another system of liability and sanctions, for instance those imposed by administrative authorities and subject to judicial control, in particular for illiciting behaviour which does not require treating the offender as a criminal.

${ }^{13}$ They are: the United Kingdom, Ireland, the Netherlands (Art. 51 of the Dutch criminal code), Belgium (according to Act of 4 May 1999, amending Article 5 of the criminal code), Luxembourg (Art. 34 criminal code), Denmark (\$ 25-25 criminal code), Finland (chapter 9 of the criminal code); France (Art. 121-2 c. p.), Portugal (Art. 11 para. 2 et seq. of the criminal code), Spain (Art. 31-bis of the criminal code), Slovenia (Art. 42 of the criminal code), Estonia ( $\S 14$ and 37 of criminal code), Lithuania (Art. 20 of criminal code), Romania (Art. 19 of the new criminal code), Hungary (Act CIV of 2001 and recently amended, providing for 'criminal measures', Slovakia (Articles 83 and 83 b of criminal code), Czech Republic (Act 418/2011), Malta and Cyprus.

${ }^{14}$ See Italian (d. lgs. 231/2001), Austrian (VbVG of 2006) Polish (law which came into force in 2003) provisions.

${ }^{15}$ It is the case of Germany and Greece. For the latest debate in Germany, see contributions in Kempf, Lüderssen, Volk (ed.), Unternehmensstrafrecht, Berlin, 2012, in particular Sachs, Ziele eines Unternehmensstrafrechts und die Frage seiner Vereinbarkeit mit dem Verfassungsrecht, 195 et seq.; Achenbach, Gedanken zur strafrechtlichen Verantwortlichkeit des Unternehmens, 271 et seq.; Beckemper, Unternehmensstrafrecht - auch in Deutschland?, 277 et seq.

${ }^{16}$ See Fiorella, From 'macro-anthropos' to 'multi-person organisation'. Logic and structure of compliance programs in the corporate criminal liability, in Fiorella (ed.), Corporate Criminal Liability and Compliance Programs, II. Towards a Common Model in the European Union, Napoli, 2012, 374 et seq.

${ }^{17}$ In general, the provisions on liability of legal persons establish that 'Member States shall take the necessary measures to ensure that legal persons can be held liable for offences (...) where such offences have been committed for their benefit by any person who has a leading position within the legal person, acting either individually or as a part of an organisation of legal persons, based on: a) a power of representation of the legal person; b) an authority to take decision on behalf of the legal person; or c) an authority to exercise control over the legal person. Member States also take the necessary measures to ensure that legal persons can be held liable where the lack of supervision or 
EU legal acts providing for ex crimine liability of entities, as an additional tool to fight criminality, generally refer to two ascription paradigms, both providing in any case that the offence must be committed 'for the benefit' of the corporate body $^{18}$. This common condition gives relevance to those illicit activities aimed at carrying out collective interests ${ }^{19}$; while the sole purpose of the perpetrator should not be an adequate basis (alongside psychological attitude, it is to consider the objective relationship between unlawful conduct and corporate interests) as well as simple advantageous outcome. In this latter case, it must be considered that what happens after the act which triggers the liability might have a role from an evidentiary point of view but it should not be identified with the condition for charging a legal entity with the fact (which is rather 'illicitly acting in the interest of the corporate body'): 'benefit' in itself should not be accepted as a touchstone of corporate criminal liability, since it is, at best, an evidential, not an operative, fact $^{20}$.

The first paradigm focuses on the prominence of the offender, acting as an individual or as part of one of the entity's organs, whenever such prominence lies on: a) the power to represent the legal person; b) the authority to form the will thereof; c) the exercise of controlling powers within it.

In brief, this pattern takes into account the position of the perpetrator insofar as the offender performs a leading (or at least considerable) function in the corporate body, by virtue of his powers of representation, decision or control. To this extent, it reflects, as is known, a common underpinning of entities' liability in many Member States, irrespective of domestic traditions (whether of common or civil law).

control, by a person referred to in paragraph 1 , has made possible the commission of an offence for the benefit of the legal person by a person under its authority'.

${ }^{18}$ Compagna, The commission of the offence 'for the benefit' of the entity, in Corporate Criminal Liability and Compliance programs, II. Towards a common model in the European Union, at fn. 10,180-184, noting that in European law emerges a constant reference to the notion of 'interest' of the legal entity, habitually conceived as a connection between the unlawful conduct and the relevant perspectives of accumulation of wealth by legal persons.

19 The wording 'for the benefit' may cause certain problems to arise with regard to involuntary offences; in these cases it seems that this criterion should be properly referred to the infringement of the duty of diligence (see, for refences to this issue in Italy, Selvaggi, Infortuni sul lavoro e interesse dell'ente. Tra «rottura» e "conservazione», l'unità del sistema di responsabilità dell'ente alla prova dei reati colposi, in Rivista trimestrale dritto penale dell'economia, 2010, 509).

${ }^{20}$ These issues are normally faced in the interpretation of domestic laws, which commonly refer to a criterion consisting in 'acting for the interest or benefit' of the corporate body. See, for Italian discipline, providing for «interesse o vantaggio" as a condition of liability, Foffani, Responsabilità da reato degli enti in Italia, in Fiorella, Stile (ed.), Corporate Criminal Liability and Compliance Programs, First Colloquium, Napoli, 2012, 93-106; De Simone, Persone giuridiche e responsabilità da reato. Profili storici, dogmatici e comparatistici, Pisa, 2012, 361 et seq.; Selvaggi, L'interesse dell'ente collettivo quale criterio di ascrizione della responsabilità da reato, Napoli, 2006, 110 et seq.; Manna, La responsabilità amministrativa delle persone giuridiche: un primo sguardo d'assieme, in Rivista trimestrale diritto penale dell'economia, 2002, 507; Ronco, Responsabilità delle persone giuridiche (diritto penale), in Enciclopedia Giuridica, XXVII, Roma, 2002; for French "pour compte», Planque, La détermination de la personne morale pénalment responsable, Paris, 2003, 283 ss.; Tricot, Corporate Criminal Liability in France, in Fiorella (ed.), Corporate Criminal Liability and Compliance Programs, I. Liability 'ex Crimine' of legal Entities in Member States, Napoli, 2012, 390 et seq.; for the austrian «zu seinen Gunsten» ( 33 of VbVG), Steininger, Verbandsverantwortlichkeitsgesetz - Ein Lehrbuch, Linz, 2006, 58; Boller, Die strafrechtliche Verantwortlichkeit von Verbänden nach dem VbVG, Wien, 2007, 160; as to the interpretation of "en su provecho", Arroyo-Zapatero, La responsabilità penale delle persone giuridiche nella penisola iberica, in Corporate Criminal Liability and Compliance Programs, First Colloquium, above at this note, 110-111; Dopico Gómez Aller, Responsabilidad de personas jurídicas, in Ortiz de Urbina Gimeno (ed.), Memento, Reforma penal 2010, Madrid, 2010, 18. 
In national implementation, it can lead to such considerations as the 'directing mind and will', according to the English scheme ${ }^{21}$, or, from a more formal point of view, which considers a sort of 'abstract identification', the positions of 'organe ou représentant', or finally a wider notion such as that of 'senior management' in which those who play a 'significant role' in making decisions concerning the corporate body or in managing or organizing the activities thereof are considered. In addition, it also depends on the choice of domestic law as to whether this prominence may be inferred in both cases of 'de jure' and 'de facto' positions ${ }^{22}$.

The second paradigm, on the other hand, which is usually regarded as an alternative, revolves around the bond between the commission of a crime and possible lack in surveillance and/or control from the abovementioned individuals; meaning, that is, that the non-fulfillment of such obligations shall have made possible the commission of the offence.

In other words, this second ascription model also allows the offences committed by subjective positions other than 'leading ones' to be taken into account, insofar as offences are due to the failure to fulfill the obligations of internal supervision. The core point is that liability of the legal entity, given the lower profile of the offender, cannot be decided on the sole basis of the position of the perpetrator but also on a causal nexus that shall exist between the offence and the said failure of supervision $^{23}$.

In light of this, EU instruments lead States towards two ascription criteria, recalling, albeit with some approximation, on the one hand the identification principle (insofar as, alias, the accent is put on the individual's prominence and embodied by those functions listed above ${ }^{24}$ and, on the other hand, a sort of vicarious liability, according to which the entity's liability can also be taken into consideration when a crime is committed by non-top managers, wherever the offence was ultimately made possible due to a lack in control over subordinates activities $^{25}$.

From this perspective, the EU seems to opt for a minimum standard.

In fact, the principle of identification is a model which, if conceived as a unique reference of a liability regime, tends to be being overcome, even in those domestic systems in which it is formed and developed, as in the case of the

${ }^{21}$ Wells, Corporations and Criminal Responsibility, Oxford, 2001, 84 et seq.; Coffee, Corporate Criminal Responsibility, in Kadish (ed.), Encyclopedia of Crime and Justice, I, New York, 1983, 259; Heine, Die strafrechtliche Verantwortlichkeit von Unternehmen, Baden Baden, 1992, 217-218.

${ }^{22}$ Valenzano, 'Triggering Persons': the role of the offender in 'ex crimine' liability of legal entities, in Corporate criminal liability and compliance programs, II. Towards a common model in the European Union, at fn. 10, 213 et seq.

${ }^{23}$ Manacorda, La responsabilité des personnes morales et l'harmonisation pénale européenne: modèles normatifs et obstacles théoriques, in La responsabilité pénale des personnes morales: perspectives européennes et internationales, above at fn. 1 , observing that, in this case, «la structure de l'imputation repose donc sur un élément ultérieur qui vient compenser l'absence du pouvoir de direction ou de représentation de la part de l'auteur personne physique» (p. 43).

${ }^{24}$ See Adam-Vermeulen-De Bondt, Corporate Criminal Liability and the EC/EU: Bridging Severeignity Paradigms for the Sake of an Area of Justice, Freedom and Security, in Adam-Colette-Basecqz-Nihoul, La responsabilité pénale des personnes morales en Europe, above at fn. 3, 399-400.

${ }^{25}$ Fiorella, From 'macro-anthropos' to 'multi-person organisation'. Logic and structure of compliance programs in corporate criminal liability, in Corporate Criminal Liability and Compliance Programs, II. Towards a Common Model in the European Union, at fn. 10, 427-428. 
United Kingdom, particularly in relation to typical corporate offences ${ }^{26}$. Experience of the English system has shown that, for various reasons, patterns of imputation based on this theory can sometimes present insurmountable limits: that explains the reasons why recent UK legislations have introduced models of responsibility for the crime of manslaughter and the offence of corruption in which there is a reference to the violation of the due diligence and prudence in the organization ${ }^{27}$.

Even the French experience, to the extent that it can be absorbed by the identification model, shows clear signs of evolution, to schemes which tend to emphasize the relationship between the offence and the organization as a whole ${ }^{28}$.

The other model, as foreseen by the legislative instruments of the European Union at least, is still 'flat' on the schemes of tort-liability (which can easily turn into risk-based approaches) and therefore not be entirely suited to the case of charging a legal entity of a criminal offence.

\section{Possible added value of an 'organisational fault' grounded system of liability for EU criminal policy}

Is developing a model of (truly) 'personal' liability grounded on an actual link between the offence and the entity, as such, necessary (or at least) suggestible for the EU? Or should one leave the liability regime to the present stage while, on the side of proper criminal offences, discipline set forth by EU directives is becoming increasingly more accurate, as far the subjective element is concerned? ${ }^{29}$

Faced with this issue, it is crucial to note that the key point is not to differentiate between criminal law of individuals (with all substantial guarantees) and liability of legal entities (where a minimum standard may be considered sufficient), but rather to find the proper path to make liability of entities a personal liability, according to characteristics of the collective subjects.

From this perspective, it should be clear that a system of effective, dissuasive and proportionate sanctions can settle permanently in an accountability regime that does not disregard considering the general attitude with respect to the offence, by giving relevance to how the corporate body aws such has carried and organized itself in

\footnotetext{
${ }^{26}$ Eser, Criminality of Organizations: lessons from domestic law- a comparative perspective, in Nollkaemper, van der Wilt, System Criminality in International Law, Cambridge, 2009, 230: 'As a consequence of this 'anthropomorphic model', the responsibility of the legal person is doomed to fail when and where responsibility of a natural person cannot be proven'.

${ }^{27}$ Gobert - Punch, Rethinking Corporate Crime, London, 2003, 21 ss.; 26 ss.; 53 ss; Wells, The Decline and Rise of English Murder: Corporate Crime and Individual Responsibility, in Crim. Law Rev., 1988, 788.

${ }^{28}$ Giudicelli-Delage, La responsabilité pénale dans l'entreprise après la loi du 10 juillet 2000, in Revue de science criminelle et de droit pénal comparé, 2001, 824; Maréchal, Plaidoyer pour une responsabilité directe des personnes morales, in La semaine juridique (édition générale), 2009, I, 249 ; Tricot, Corporate criminal liability in France, in Corporate criminal liability and compliance programs, First Colloquium, above at fn. 14, 144.

${ }^{29}$ See Boccon-Gibod, Sur la responsabilité des personnes morales. Perspectives européennes, in Giudicelli-Delage, Manacorda, La responsabilité pénale des personnes morales, at $\mathrm{fn} .1,113$ : «(..) la discussion reste ouverte sur le fondement d'une telle responsabilité : - doit-elle se concevoir par emprunt de la criminalité d'une personne phisique $(\ldots)$ ? - ou doit-elle être définie comme autonome, reposant sur une faute personnelle de la personne morale (...) ?»
} 
order to prevent or (on the contrary) to facilitate the commission of the offence; which obviously means focusing first of all on the adoption and implementation of adequate preventive measures and, from a theoretical point of view, to the concept of organisational fault, as '(...) a company's culpable failure to prevent businessrelated crimes that could have been averted had proper attention been paid to the risk of criminality ${ }^{30}$.

In fact, on the side of proportion ${ }^{31}$, by considering an entity responsible as to whether a 'structural negligence' thereof exists ${ }^{32}$, it seems possible narrowing the punishment of legal entities when necessary (that is for certain in any case organizational shortcomings or corporate policy or culture are the roots of the offence; but not in any case an offence occurred in a collective and organized context); appreciating the real involvement of the corporate body and so tailoring the sanction: an evaluation over the degree of real participation of the corporation, in other words, leads to better sentencing ${ }^{33}$.

Furthermore, giving relevance to an 'organisational fault' could help to develop an element such as that in traditional criminal law which corresponds to the psychological (or moral) element of the offence, thus addressing the theoretical, constitutional and policy objections according to which liability of legal entity is strict $^{34}$. As is known, these objections are traditionally raised up by arguing that a collective entity would not have a guilty mind and have brought, at a first stage, to the idea of identification between agent and entity.

On the other hand, a system aimed at giving relevance to the general attitude of a legal entity (at least in tendency), in terms of organization, policy and culture, could better ensure the goal of prevention of crimes typically associated with collective activities, especially entrepreneurial, acting on their structural causes: by exonerating them from liability, corporations are encouraged to set up controls over their own activities and organizations and to adopt procedures in order to prevent

\footnotetext{
${ }^{30}$ Gobert-Punch, Rethinking Corporate Crime, above at fn. 25, 86, adding that '(...) a company's gross negligence would be found not in the gross negligence of any employees, or even in the aggregated negligence of all of its employees, but rather in the company's failure to prevent its employees from behaving in a negligent or illegal manner'.

${ }^{31}$ See, for the interpretation and impact of 'proportionality' and its relationship with subsidiarity principle, Sotis, $I$ principi di necessità e proporzionalità della pena nel diritto penale dell'Unione Europea dopo Lisbona, in www.dirittopenalecontemporaneo; Manes, Il giudice nel labirinto. Profili delle intersezioni tra diritto penale e fonti sovranazionali, Roma, 2012, 144 et seq.; Herlin-Karnell, The constitutional dimension of European criminal law, above at fn. 8, 116 et seq.; Ashworth, Sentencing and Criminal Justice, Cambridge, 2005, 147-148;

${ }^{32}$ As outlined, it is first of all in structural negligence that can be located the 'blame' that warrants attaching criminal liability to a company; with regard to italian discipline, "(...) the company needs to have established guidelines and control systems that take into account the risk of the offence being committed. If it has not, then it will be found to be 'structurally negligent»: Gobert-Punch, Rethinking Corporate Crime, above at fn. 25, 111.

${ }^{33}$ With reference to the activity of fining companies in English law, Ashworth, Sentencing and Criminal Justice, above at fn. 28, 310-311; also, Laufer, Culpability and The Sentencing of Corporations, in 71 Neb. L. Rev. 1049 (1992).

${ }^{34}$ On this debate, Fiorella, From 'macro-anthropos' to 'multi-person organisation'. Logic and structure of compliance programs in the corporate criminal liability, in Corporate Criminal Liability and Compliance Programs, II. Towards a Common Model in the European Union, at fn. 10, 398 et seq.; Nieto Martín, La responsabilidad penal de las personas juridicas: un modelo legislativo, Madrid, 2008, 127 et seq.; Schünemann, Strafrechtliche Sanktionen gegen Wirtschaftsunternehmen?, in Strafrecht und Wirtschaftsrecht. Festschrift für Klaus Tiedemann zum 70. Geburtstag, Köln, 2008, 430-440; Paliero, Das Organisationsverschulden, ibidem, 503 et seq.; Wells, Corporations and criminal responsibility, above at fn. 20, 78 et seq.; 155 et seq.
} 
the commission, for their benefit, of any offence ${ }^{35}$. This should grant an effective implementation of EU criminal policy, which is focused on ensuring actual and stronger crime prevention, especially in economic fields and in other areas where corporations may play a significant role.

Finally, a more articulated regime would permit entities to effectively defend themselves in the process and prove that they do not have anything to do with the offence committed.

\section{Plaidoyer of a 'step forward' in EU discipline}

'Specifics' of ex crimine liability (whether proper criminal liability or a type of liability similar thereof) call for an innovation of the imputation mechanism that can be shaped by EU acts, in order to give relevance (introducing a specific imputation criterion or at least providing for a defence) to the general attitude of the corporate body; and open the way for a legal entity which is properly and effectively organized to be insulated from responsibility.

Apart from what can be taken from the analysis of National legal orders, especially in recent years, it has to be noted, conversely, how an interesting indication could be derived from the already mentioned Recommendation from the Council of Europe [R (88) 18]. The said instrument is, indeed, interesting in several respects.

On the one hand, it implies the chance to ascribe an offence to a legal person even where it is not possible (in concrete terms) to single out one or more individuals responsible for the misconduct; on the other hand - and even more importantly so for our analysis - it clearly indicates those elements which may be used to exclude the entity's responsibility for the offence: first of all, the fact that the management is not implicated in the offence; secondly, the adoption of measures adequate to prevent the commission of crimes which reflects an irreproachable exercise, on the part of the entity, of all the due diligence ${ }^{36}$.

EU policy in this field might follow this line of enhancing the connection between offence and organization, taking into account not only the position of the perpetrator+, but also that of the entity, which may be overall and preventively organized in such a way that appears virtuous 'ex ante', reducing to an acceptable extent the risk of offences which might be committed in the course of collective

\footnotetext{
${ }^{35}$ Sieber, Compliance-Programme im Unternehmensstrafrecht, in Festschrift für Klaus Tiedemann zum 70. Geburstag, KölnMünchen, 2008, 449-484; with regard to possible developments of those discipline providing for 'compliance programs', Severino, 'Omogeneizzazione' delle regole e prevenzione dei reati: un cammino auspicato e possibile, in Fiorella, Stile (ed.), Corporate Criminal Liability and Compliance Programs, First Colloquium, above mentioned at fn. 20, 433 et seq.,

${ }^{36}$ It is interesting to note that in the mentioned Recommendation $\mathrm{n}$. R (88) 18 , attention is called to the fact that to render enterprises liable, consideration should be given in particular to 'applying criminal liability and sanctions to enterprises, where the nature of the offence, the degree of fault on the part of the enterprise, the consequences for society and the need to prevent further offences so require'.
} 
activities and, from this point of view, without 'fault' on the part of the corporate body (since the commission of the offence would be ergo 'unforeseeable').

In this perspective, an interesting example may be found in a recent draft proposed by a group of scholars, in the frame of a research granted by the European Commission, particularly focused on constructing a subjective attitude of the entity, expressed prior to the commission of an offence, as a grounding element of the liability regime ${ }^{37}$. This draft not only details the ideal paradigm and fundamental structure of 'compliance programs' able to exonerate an entity from liability, but also gives much importance to 'fraudulent circumvention' of the preventive models and controls by perpetrators acting in a top-management position. In fact, this fraudulent activity - in other words, side-stepping the rules laid down by the corporation - becomes the watershed between the individual will and the corporate body's attitude.

\footnotetext{
${ }^{37}$ Such research has been carried out by Roma Tre University, Sapienza University of Rome, Panthéon-Sorbonne University of Paris and Castilla La Mancha University. The outcome of the research has been published in Fiorella (ed.), Corporate Criminal Liability and Compliance Programs, II. Towards a Common Model in the European Union, at fn. 10, 433 et seq.
} 